\title{
Trust in Companies and in CEOs: A Comparative Study of the Main Influences
}

Diana Ingenhoff
Katharina Sommer
ABSTRACT. Trust is a crucial factor for the long-term economic success of a company. However, not only does the company establish trust, but the CEO representing the company builds up trust as well and, therefore, also influences the company's success. Our study examines how different dimensions of trust (i.e., ability, integrity, benevolence, and information quality) influence the degree of overall trust in a company and in CEOs. Nevertheless, dimensions that influence trust in a CEO can be completely different to those influencing trust in companies. Companies and CEOs that act on an international level can hardly be experienced individually, and thus people get information about the company via media use. Therefore, additionally we examine which kind of media is used for getting information about a company or CEO and whether a relationship exists between media use and trust. Findings from a survey in Switzerland $(n=245)$ show that companies are more trusted than CEOs and that the items which influence overall trust differ between CEOs and companies. Social responsibility as a benevolence item is important for both groups. Regarding information on different media channels, users of traditional media like newspapers, TV, and radio are most critical regarding trust in companies and CEOs.

KEY WORDS: dimensions of trust, trustworthiness, organizational trust, interpersonal trust, benevolence, ability, integrity, social responsibility, trust building

\section{Introduction}

Trust in companies is regarded as a fundamental element of corporate success, because it builds and supports long-term relationships between a company and its stakeholder groups and, therefore, generates supportive behavior while preventing unsupportive behavior (Caldwell et al., 2008a; Grunig et al., 2002;
Hon and Grunig, 1999; Huang, 2001; Ki and Hon, 2007). As a social mechanism, it plays an important role in the transaction cost approach, because it lets the organizations react more flexibly to changing market conditions by saving time in the transaction process. They are able to contract less ex ante than without trust (Cummings and Bromiley, 1996; Dyer and Chu, 2003; Möllering et al., 2004; Zaheer et al., 1998). Trust can be seen as the opposite of opportunistic action. When trust is strong, less governance structures such as safeguards in transactions are needed to prevent opportunism, and, therefore, costs for the organization decrease. Thus, trust leads to a competitive advantage (Barney and Hansen, 1994; Sako, 1998). As negotiation and dialogue between a company and stakeholder groups are highly relevant, especially in conflict management, trust leads to stronger cooperative behavior (Christen, 2004).

Not only is the company as a collective player a key factor, but also is trust in the companies' Chief Executive Officers (CEOs) because the CEOs represent the company and, therefore, have a strong impact on the corporate image (Park and Berger, 2004; Skolnik, 1994) which in turn influences trust building. Therefore, stakeholders' trust-building can be analyzed on two levels: On the one hand, there is individual trust in a CEO and on the other, in the company as collective trustee. Organizations are expected to be more stable than individuals, because "institutional arrangements [...] make significant dishonesty risky, even difficult" for companies, more than for an individual (Hardin, 1991, p. 204). Nevertheless, both individual and organization need the reputation they have established.

The first aim of our study is to analyze which elements influence trust building for both company 
and CEO, against the background of this interdependency between trust in a company and in its CEO. We consider the dimensions of ability, benevolence, and integrity that form trust in both a company and a CEO (Caldwell and Clapham, 2003).

As individuals very seldom have direct, personal contact with the company except through its products and services, information from the media about an international company or CEO is the basic source of information for building trust. Therefore, our second aim is to find out what kind of media is used by the respondents for becoming informed about trust-building behavior. We address these two research questions by means of a standardized survey in Switzerland.

\section{Theoretical foundations and research questions}

In the present research, there is a confusing variety of different definitions of trust, which is basically a consequence of the construct's complexity. Trust is regarded as a central construct in various scientific disciplines such as philosophy, economics, sociology, and political and communication sciences, which have different approaches as a matter of course (Hosmer, 1995). One reason for the growing interest in trust is based on the awareness that social changes and a growing differentiation of roles result in a need for trust as a basis and an alternative to the eroded traditional social structure. Therefore, trust is regarded as a key concept for a functioning modern society (Hardin, 2006; Kohring and Matthes, 2007; Möllering et al., 2004).

Furthermore, trust refers to different levels of trusted individuals or parties (Zaheer et al., 1998). Trust can be built for others in general (dispositional trust) or for a real exchange partner (relational trust), which can be individual or collective. First, we focus on the general nature of trust and explain the relationship between entrusted (trustor) and trustee. The trustor is defined as the origin of trust while the trustee is its referent (Mayer et al., 1995). Second, we analyze the different dimensions that build trust. Third, we distinguish between the personal and organizational levels of trust and specify the definitions of trust that undergird the study and frame the research questions and hypotheses for the subsequent study.
The nature of trust

Coping with risky situations is an important dimension in the definition of trust throughout the different approaches and disciplines: Only when risk and uncertainty exist, is there a need to trust (Hardin, 2006; Mayer et al., 1995). Therefore, vulnerability is central to this understanding. In our study, we define trust as an attitude of a trustor toward a trustee in a risky situation for the trustor. Trust is built on evaluations of the trustee's ability, integrity, benevolence, and information quality by the trustor.

Trust is a construct that enables people to cope with risks and, therefore, to interact with other people, despite an existing informational imbalance (McAllister, 1995). The trusted party has more information regarding the topic and thus the trustor has to expect that the trustee will act according to the benefits of the trusting person.

Mayer et al. define trust as "the willingness of a party to be vulnerable to the actions of another party based on the expectation that the other will perform a particular action important to the trustor, irrespective of the ability to monitor or control that other party" (Mayer et al., 1995, p. 712). This definition can be extended with the understanding of trust as "an expression of faith and confidence that a person will be fair, reliable, ethical, competent, and nonthreatening" (Carnevale, 1995, p. xi). Caldwell and Clapham define trust according to the definition by Mayer et al. mentioned above: Trust is "the subjectively perceived point on a continuum at which a group or organization's behavior is perceived as complying with the ethical duties considered to be owed to the person or organization who is making the decision to trust" $(1995$, p. 356$)$.

Hardin describes the motivation of trust-building by defining trust as "encapsulated interests." First of all, the trustee wants to maintain the ongoing relationship with the trustor "because it is not merely the present fulfillment that matters but also all that might come from [their] long-run future interactions" (Hardin, 2006, p. 19). Even if no direct relationship exists, the trustee might encapsulate the interests of the trustor because he wants to maintain his reputation and trustworthiness. His motivation can be moralistic or selfish, direct, or indirect. What matters is that the trustee acts in favor of the trustor's expectations. Trust is a temporal phenomenon, 
because it builds upon the experiences, perceptions, and interactions of the trustee (Caldwell and Clapham, 2003). It is a basis for future action (Luhmann, 1979; McAllister, 1995; Shapiro, 1990).

Although trustworthiness is often understood as a synonym for trust (Christen, 2004), a differentiation between trust and perceived trustworthiness is needed, because the decision to trust is based on the trustworthiness of the other person, i.e., the trustee (Caldwell and Clapham, 2003, 2008a, b). Trustworthiness is "a subjectively defined attribution about another person or party that is determined by each person at the individual or organizational level" (Caldwell et al., 2008b, p. 158). Therefore, perceived trustworthiness is based on the subjective evaluation of different characteristics and behavior of the trustee. Trust can, therefore, be defined as a multidimensional construct comprising different dimensions of the trustee's attributes that the trustor evaluates.

Trust as a multidimensional construct: dimensions of trust building

Trust is based on trustworthiness and, therefore, on the perception of competence, responsibility and dependability of the trustee. Thus, it is modeled as a multidimensional construct, based on cognitive and affective elements (Butler, 1991; McAllister, 1995). On the one hand, people decide for good reasons they decide in a cognitive way whether to regard the other as trustworthy or not. On the other hand, emotional bonds between the trustor and the trustee have an affective impact on trust building (Lämsä and Pucetaite, 2006; McAllister, 1995). These bonds are assumed to be reciprocal and individuals have to know each other personally - they have to interact frequently to develop these emotional bonds. When the trustor has no direct experience with the trustee, reputation is an important dimension, because the trustor assumes that the trustee will act in a trustworthy way to avoid losing his good reputation (Hardin, 2006).

Concerning "good reasons," the cognitive reasons for trusting, the dimensions ability, integrity, and benevolence are of importance in this research (Caldwell et al., 2003; Mayer et al., 1995). Antecedents of these three dimensions are developed by Butler and Cantrell (1984), who differentiate between integrity, consistency, loyalty, openness, and competence and, therefore, account for morality with the first four dimensions as well as for ability with the competence dimension (Butler, 1991; Hosmer, 1995). Sako (1998) distinguishes among three types of trust that also include the facets mentioned above: contractual trust referring to the fulfillment of contractual agreements, competence trust referring to the ability to actually do the things promised and goodwill trust referring to the ability to make an open-ended commitment to take initiatives for mutual benefit while refraining from unfair advantage taking.

According to Mayer et al., ability is understood as competence within a certain field and thus as expertise. Caldwell and Clapham split the three dimensions ability, integrity, and benevolence into seven facets. Competence, quality assurance, and financial balance can be related to ability (1995, p. 352). Integrity is defined as the perception of the trustee as having a strong sense of justice and acting according to it. It is measured by the perception of the trustor (1) to what extent a congruency exists between the activities and the promises a party gives and (2) whether the trustee develops a procedural fairness and transparency toward the trustor. Finally, benevolence describes the trustees' attempts to do good to the trustors without thinking of their own benefit. For measuring benevolence, Caldwell and Clapham define (1) interactional courtesy and thus the degree of respect for others by acting; and (2) the responsibilities of the trustee to inform the trustor about the activities (Caldwell and Clapham, 2003; Mayer et al., 1995).

Another dimension that influences trust in a company or a CEO is information quality. When the trustee's given information is comprehensible, the trustor is more willing to build trust (Bentele, 1994; Nawratil, 1999; Rühl, 2005; Wirth, 1999), and the perceived transparency of the company and/ or the CEO is strengthened. Bentele traces it back to basic individual social trust, which is generated within the socialization process. Therefore, correlates of behavior make it possible to judge between honest and dishonest behavior and are, therefore, the bases for trust building in general (Bentele, 1994).

The elements of ability, integrity, benevolence, and information quality concern the trustees, because they represent their perceived trustworthiness. For building trust in the trustee, the trustor has to evaluate different dimensions of trustworthiness that form 
trust and, therefore, perceived characteristics and former actions of the trustee lead to trust-building (Mayer et al., 1995).

\section{Trust in an individual and in an organization}

Trust on the organizational level between an individual trustor and an organization or an organizational representative as trustee is closely related to interpersonal trust between two individuals who know each other personally. The origin of trust lies in the individual, whereas the referent, the trusted party, can be both individual and collective (Zaheer et al., 1998).

Trust on the organizational level means that trust is generated by the behavior of the company that should be trusted (Caldwell and Clapham, 2003; Mayer et al., 1995). This understanding of trust fits into the trusting relationship between individual stakeholders and a company as a collective actor. Where trust in a CEO is concerned, there is an even stronger correspondence to interpersonal trust, because two individuals, the stakeholder and the CEO, are involved. However, the CEO does not know the individual stakeholder in person, and, therefore, the relationship is not reciprocal on an individual level.

Trust in a company as a collective actor and in the $\mathrm{CEO}$ as a representative can be completely different: A company can be trusted to another degree than the individuals that work for the company (Currall and Inkpen, 2002). Thus, trust in the CEO and the company are important for decision-making processes of individuals (Möllering and Sydow, 2005).

In order to analyze whether differences exist between the evaluation of companies and CEOs, we compare the findings of these two levels. Therefore, we develop only one instrument to measure trust in a company and in a CEO.

In order to analyze how trust is built for internationally active companies and CEOs, we focus on the following first research question and two hypotheses:

RQ1: Which elements influence trust in a company as a collective trustee and in the CEO as a single trustee?

H1: There is a difference between the degree of trust in the companies and in the CEO.
H2: There is a difference between the dimensions that influence trust between the companies and the CEOs.

\section{Trust and media use}

The missing reciprocal relationship between trustor and trustee on the organizational level implies that individuals get most information about the trustee from media coverage. Thus, when evaluating CEOs and companies, individuals will primarily think of information they got through media coverage. Considering the size of the organizations that act on an international level, it is unlikely for respondents to have personal experience with the company's CEO beside products and services (Bentele, 1994; Bentele and Seidenglanz, 2005; Nawratil, 1999).

When people use traditional media like television news, newspapers, and radio to get information about a company or CEO, they obtain general and less detailed information about various economic topics. In contrast, users of the Internet, company homepages, and special-interest journals can perform much more detailed searches and, therefore, are more likely to get special information about a company and/or CEO. Hence, variety of choices in news coverage is especially important as perceived "gratification-opportunity" regarding motivation for using Internet sources for news (Dimmick et al., 2004). In studies about the Internet and political information, the Internet is regarded as a medium that serves information seeking needs and that provides special information which is easy to obtain. Whether using the Internet to locate special information has a positive impact on trust in the government remains an open question regarding political communication. Initial studies could not identify a significant relationship (Kaye and Johnson, 2002). As users of special media sources like the Internet, company homepages, and special-interest journals are able to vary their news sources and decide about the combination of information, we expect that respondents who use special media sources feel more adequately informed. They, therefore, tend to have a different level of trust in the companies than the people who get more general information from traditional media. As special 
information can lead either to more or less trust, we do not define whether trust is higher or lower for people who use traditional media.

As people who rely on special information sources and the traditional media are best informed about the activities of the company and/or CEO in question, they will feel more adequately informed and have a higher level of trust than people who do not use any media for getting information about the company at all.

The second research question addresses the role of media use for trust building on an organizational level. We ask, therefore, which media the respondents use for getting information about the company/CEO in question and whether the use of different types of media reveals a correlation with the degree of trust.

RQ2: Does the use of different media sources for getting information about internationally active CEOs/companies correlate with the evaluation of the CEOs/companies?

H3: Respondents who use traditional media sources evaluate trust dimensions in a different way than respondents who use special media sources for getting information about the company/CEO.

H4: Respondents, who use both traditional and special media sources evaluate trust dimensions more positively than respondents who infrequently use media coverage for getting information about the company/CEO (Figure 1).

\section{Research design}

In order to answer the research questions, we conducted a standardized, written survey. The object of investigation is not one multinational acting com-

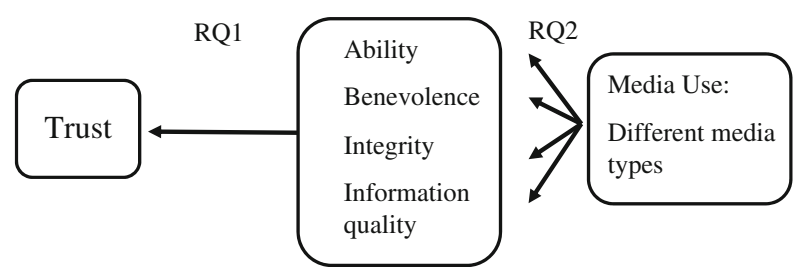

Figure 1. Trust in companies and in CEOs: research questions. pany or one CEO, but different ones: ${ }^{1}$ People responded to questions regarding the company or the CEO of their own choice. Respondents had to name a company or CEO in the beginning and answer the questions in light of their choices. By mentioning a company/CEO for which/whom the respondents answer the survey questions, we made sure that people knew the company or the CEO about which/whom they had to answer the questionnaire. In order to compare the results of the two objects of investigation, we developed a similar questionnaire for companies and CEOs.

In the survey, we included questions regarding the four dimensions of influence on trust. For an overview over the items for ability, integrity, benevolence, quality of information, and trust (global variable), see Appendix Table VIII.

Ability was defined as expertise, competence, and an assurance of quality (Caldwell and Clapham, 2003; Mayer et al., 1995). Thus, we measure ability according to the following items: whether the company/CEO is economically successful, whether it/she/he stands for product quality, and whether it/ she/he works with comprehensive attention to detail. Integrity means that the trustee shares principles with the trustor and acts upon them (Mayer et al., 1995). According to Caldwell and Clapham, this means legal compliance and procedural fairness (Caldwell and Clapham, 2003). In order to operationalize integrity, we asked whether the activities of a company/CEO are perceived as being in accordance with its promises and whether it/she/he demonstrates law-abiding behavior. To explain the construct of benevolence, Mayer et al. give the following example: "The mentor wants to help the protege, even though the mentor is not required to be helpful, and there is no extrinsic reward for the mentor" (Mayer et al., 1995, p. 719) This is exactly what happens when a company or CEO acts in a socially responsible way. Caldwell and Clapham also mention the responsibility to inform as a benevolent characteristic. Therefore, we measured benevolence with items regarding the perception of social responsibility of the company and the CEO, and extensive public information about corporate activities.

Quality of information is also important for building trust, because it strengthens transparency and reliability (Wirth, 1999). We asked the respondents to 
evaluate the quality of information regarding its objectivity and factual basis and its factor of intelligibility.

Every item was formulated as a statement that the respondent had to evaluate on a scale from $1=$ "strongly agree" to $5=$ "do not agree at all."

In order to test the influence of these dimensions on trust and sympathy for the CEO/the company, we included a manifest variable that directly measures the perceived trust the trustor has for the mentioned company/CEO. The respondents had to answer how intense they regard their trust in and sympathy for the specific company/CEO (scale from $1=$ "very" to $5=$ "not at all").

For analyzing how the media use relates to trust building in companies or CEOs, the respondents had to answer how often they use different media types to get information regarding the company/CEO in question on a scale from $1=$ "everyday" to $5=$ "never."

Finally, the respondents' socio-demographic characteristics such as sex, age, and education level were surveyed.

\section{Sample}

Overall, we surveyed people in three Germanspeaking cities in Switzerland in $2007(n=245) .120$ respondents answered questions regarding a CEO, and 125 were asked about a company chosen by themselves.

In order to get random samples, every third person, who passed the interviewers in three main locations in three cities in Switzerland, was approached to answer the questionnaire.

In both samples, there is nearly a gender balance (CEOs: 61\% male and 39\% female respondents, companies: $48 \%$ male, $52 \%$ female). The age of the respondents averaged 40 years, whereas $50 \%$ were under the age of 35 .

As shown in Table I, most of the respondents are employees without any executive position in the company (sample CEO: 48\%, companies: 40\%), around $22 \%$ are students (sample CEO: $20 \%$, companies: $25 \%$ ), and around $13 \%$ of the respondents are employees in management positions (sample CEO: $14 \%$, companies: $13 \%$ ). We also ask the respondents for the type of company they work for to control for
TABLE I

Percentage of professions mentioned by respondents

\begin{tabular}{lrc}
\hline & \multicolumn{2}{c}{ Sample } \\
\cline { 2 - 3 } & CEO & $\begin{array}{c}\text { Company } \\
(n=118)\end{array}(\%)$ \\
& $(n=124)(\%)$ \\
\hline Employee in management & 14 & 13 \\
position & & \\
Employee without & 48 & 40 \\
management position & & \\
Self-employed & 8 & 7 \\
Trainee & 3 & 3 \\
Student & 20 & 25 \\
Pupil & 2 & 2 \\
Housewife & 1 & 5 \\
Unemployed & 2 & 4 \\
Other & 2 & 100 \\
Total & 100 & \\
\hline
\end{tabular}

differences in knowledge about the structures and processes of international companies. About 39\% of the employees do not work in a for-profit company at all (sample CEO: 32\%, companies: 45\%) and about $10 \%$ work for a company that acts internationally (sample CEO: $11 \%$, companies: $8 \%$ ).

\section{Results}

Difference in the degrees of trust in companies and in CEOs

Hypothesis 1 states a difference in the degrees of trust in companies and in CEOs. We tested the differences of the arithmetic means between CEOs and companies by means of a $t$-test for independent samples (Tables II, III).

Results show that trust in CEOs is significantly lower than trust in companies (arithmetic mean of 3.04 and 2.61 on a five-point-scale with $1=$ "agree totally" and $5=$ "do not agree at all"), which corresponds to the rating of sympathy (AM $=3.07$ and 2.68). That means that companies as collective trustees are able to generate more trust and sympathy than $\mathrm{CEO}$ as the individual trustee.

A comparison between companies and CEOs regarding the ranking of the different items supports 
TABLE II

Arithmetic means and standard deviations of variables for the samples in respect of CEOs and companies

\begin{tabular}{|c|c|c|c|c|c|}
\hline & \multirow[t]{2}{*}{ Variables } & \multicolumn{2}{|c|}{ Arithmetic mean } & \multicolumn{2}{|c|}{ SD } \\
\hline & & $\begin{array}{c}\text { CEO } \\
(n=120)\end{array}$ & $\begin{array}{l}\text { Company } \\
(n=125)\end{array}$ & $\begin{array}{c}\text { CEO } \\
(n=120)\end{array}$ & $\begin{array}{l}\text { Company } \\
(n=125)\end{array}$ \\
\hline \multirow[t]{3}{*}{ Ability } & Economic success & 1.57 & 1.37 & 0.776 & 0.561 \\
\hline & Product quality & 1.90 & 1.80 & 0.909 & 0.893 \\
\hline & Detail-orientation & 2.22 & 2.24 & 0.949 & 0.926 \\
\hline \multirow{2}{*}{ Integrity } & Activity in accordance with promises & 2.54 & 2.28 & 0.897 & 0.984 \\
\hline & Law-abiding behavior & 2.59 & 2.42 & 1.064 & 1.094 \\
\hline \multirow{2}{*}{ Benevolence } & Social responsibility & 3.24 & 3.06 & 1.127 & 1.132 \\
\hline & Extensive public information & 3.23 & 2.88 & 0.983 & 0.947 \\
\hline \multirow[t]{2}{*}{ Information quality } & Objectivity & 2.17 & 2.14 & 0.792 & 0.886 \\
\hline & Intelligibility & 2.53 & 2.27 & 0.898 & 0.912 \\
\hline Trust & Global variable & 3.04 & 2.61 & 1.08 & 0.985 \\
\hline Sympathy & Global variable & 3.07 & 2.68 & 1.128 & 1.137 \\
\hline \multirow[t]{6}{*}{ Media use } & News on TV & 2.96 & 3.17 & 1.108 & 1.085 \\
\hline & News on Internet & 3.33 & 3.47 & 1.346 & 1.295 \\
\hline & News on homepage & 4.25 & 4.01 & 1.075 & 1.24 \\
\hline & News on radio & 3.49 & 3.69 & 1.073 & 1.136 \\
\hline & News in newspapers & 3.12 & 3.29 & 1.202 & 1.202 \\
\hline & News special-interest magazines & 3.82 & 3.85 & 1.24 & 1.073 \\
\hline
\end{tabular}

TABLE III

$T$-values for arithmetic differences between the group companies and CEOs

\begin{tabular}{lll}
\hline & \multicolumn{1}{c}{ Variables } & $\begin{array}{c}T \text {-values for } \\
\text { difference }\end{array}$ \\
\hline Ability & Economic success & $2.335^{\star \star}$ \\
& Product quality & 0.805 \\
Integrity & Detail-orientation & $4.057 \star \star$ \\
Benevolence & Activity in accordance with promises & $2.150^{\star}$ \\
& Law-abiding behavior & 1.225 \\
Information quality & Social responsibility & 1.236 \\
& Extensive public information & $2.798^{\star \star}$ \\
Trust & Objectivity & 0.219 \\
& Intelligibility & $2.306^{\star}$ \\
& Global variable & $3.241 \star \star$ \\
\hline
\end{tabular}

$\star$ Significant with $p \leq 0.05 ; \star \star$ Significant with $p \leq 0.01$.

these findings. Companies are consistently better evaluated in all the categories. In particular, the items of economic success, comprehensive attention to detail (detail-orientation), activity in accordance with promises, extensive public information, and comprehensible information (intelligibility) are ranked significantly higher for companies than for CEOs.

Thus, hypothesis 1 is confirmed: there is a difference between the degrees of trust in a company and in a CEO, because trust in a company is evaluated systematically higher than trust in CEOs. 
Impact of different dimensions on trust

Hypothesis 2 focuses on how the dimensions ability, integrity, benevolence, and information quality influence trust in companies and in CEOs. We analyzed the effects by calculating two regression analyses for the two samples. As the standard errors can be biased in small samples when outliers in the residuals exist, we controlled the analyses for outliers (Urban and Mayerl, 2006). Hence, we excluded six cases for the CEO sample and three cases for the company sample to obtain reliable significances. In order to rule out multicollinearity, we calculated tolerances for the explanatory variables. Tolerance measures how much of the variance of one explanatory variable is explained by the other independent variables. The lowest tolerance scores are 0.46 (in the company sample for law-abiding behavior) and 0.49 (in the CEO sample for extensive public information). This means, that these items have more than $50 \%$ free variance which can explain the dependent variable. Therefore, it could be shown that each item has for itself a high explanatory potential for trust, although the correlations between the items are mostly significant (see Appendix Table IX).

The first regression analysis shows that trust in CEOs is influenced especially by items that belong to the benevolence and to the integrity component of trust: being socially responsible and by acting in accordance with promises. Ability also explains trust in CEOs by the item of working with comprehensive attention to detail. Nevertheless, information quality has no significant influence on trust in CEOs. In the second regression analysis, trust in companies is strongly explained by the item respect for laws and, therefore, by integrity. Benevolence is also a strongly influencing dimension in our regression analysis because both items, extensive public information and social responsibility of the companies, are significantly influential. Finally, quality of the products, and thus ability, also explains trust in internationally acting companies, whereas information quality has no significant impact in this sample (Table IV).

Results indicate that for CEOs as well as for companies, ability, benevolence, and integrity are significantly important for trust building, whereas the influence shifts slightly from a balance between the three dimensions on trust in CEOs to a dominance of benevolence on trust in companies. Information quality shows no significance at all. As hypothesis 2 assumes that the four dimensions are important for building trust although the importance of the facets differs between companies and CEOs, it can be confirmed only partially.

Differences in evaluating trust dimensions between users of different media types

The second research question deals with the relationship between the use of media types and trust. Here, we merged the data sets of CEO and company in the analysis.

First, we calculated an explanatory factor analysis (main components, Varimax-rotated). With this analysis, we tested whether media use can be separated into the use of traditional and/or special media sources.

Factor analysis shows that the variables can clearly be classified as use of traditional and/or special media sources. On the first factor extracted, news on TV, in newspapers, and radio news loaded with at least 0.73 (newspapers); the second factor has high loadings of the use of special-interest journals, news on the Internet, and news on the homepage with at least 0.62 (special-interest journals). Both factors are able to explain $61 \%$ of the variance. Therefore, the separation of media use into traditional versus special media sources is supported by this finding (Table V).

Hence, in the second step we divided the respondents into user-groups. First of all, we differentiated between frequent and infrequent media use. In our questions regarding media use we distinguished between "every day," "at least once a week," "at least once a month," "less than once a month" and "never." We drew the line between users, who use a medium at least once a week and less than that. We defined the first group as that which uses all proposed media options only infrequently and, therefore, less than once a week to get information about the company/CEO $(n=102)$. The second group uses traditional media frequently $(n=50)$, the third group uses special media sources frequently $(n=27)$, and, finally, the fourth group uses both traditional and special media sources frequently $(n=54)$.

In order to test hypothesis 3 , we compared means between the groups of special and traditional media users of the variables that build trust and the trust variable itself. 
Trust in Companies and in CEOs

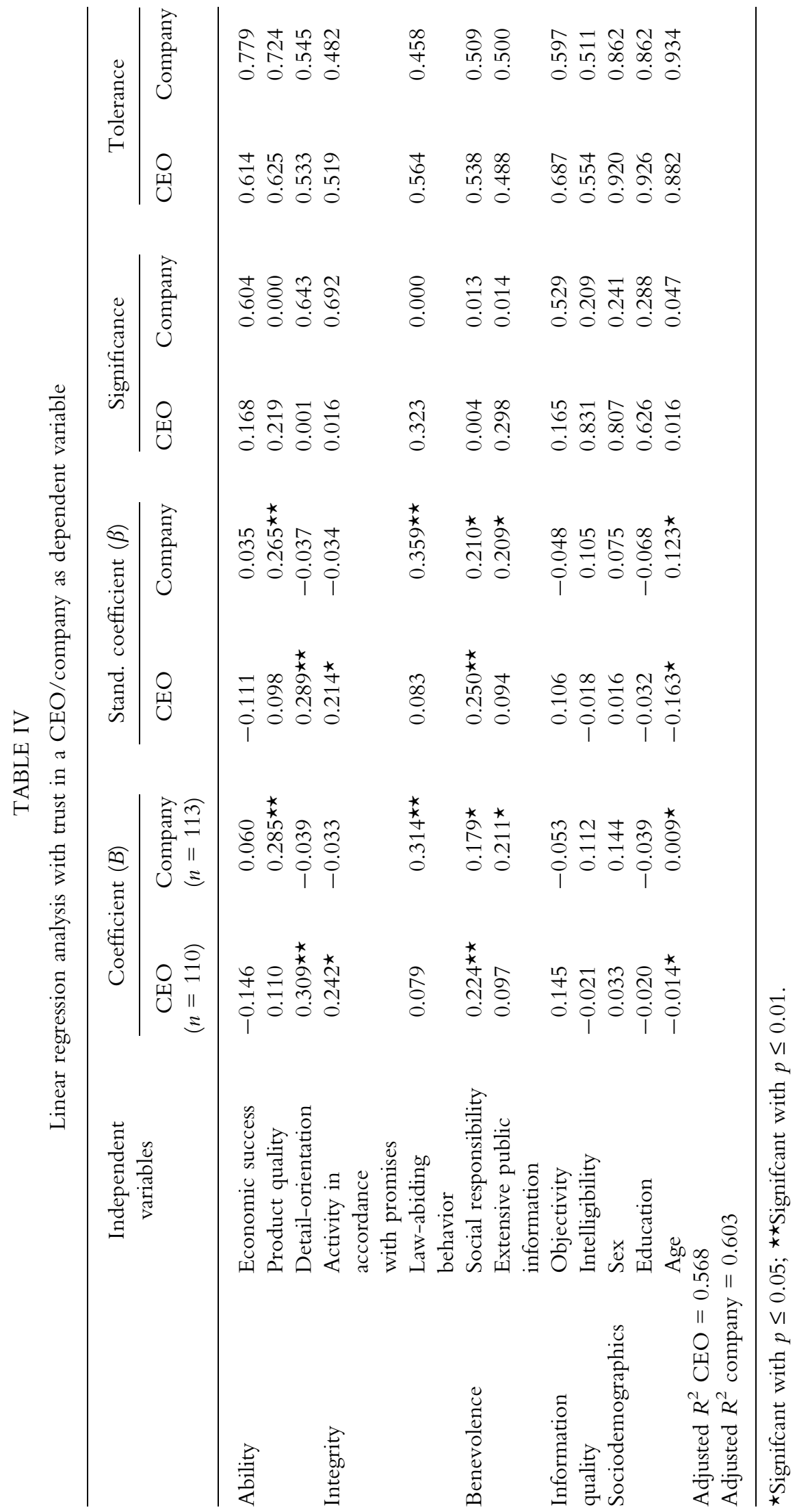




\section{TABLE V}

Explorative factor analysis for media use for information about company/CEO

\begin{tabular}{llcc}
\hline \multicolumn{1}{c}{ Variables } & $\begin{array}{c}\text { Factor 1: use of } \\
\text { traditional media }\end{array}$ & $\begin{array}{c}\text { Factor 2: use } \\
\text { of specific media }\end{array}$ \\
\hline Media use & News on TV & 0.731 & \\
& News on radio & 0.752 & \\
& News in newspapers & 0.768 & 0.770 \\
& News on Internet & & 0.858 \\
& News on homepage & & 0.617 \\
$R^{2}$ & NEWS special-interest magazines & & \\
\hline
\end{tabular}

Principal components, Varimax-rotated, $n=245$, loadings $>0.04$ included.

Against our assumption, the global variable trust and the items for information quality do not differ between the groups. Just the items - adequate public information and social responsibility and, therefore, the evaluation of the benevolence of the company/ CEO - reveal differences. These items are significantly more positively evaluated by users of special media sources coverage than by users of traditional media. This means that people, who use Internet news, homepages, and special-interest journals for getting information about a company/CEO, do honor benevolent activities more than the users of television news, newspapers, and radio.

Thus, hypothesis 3 can only partially be confirmed for the evaluation of the company's/CEO's benevolent behavior, because the items of integrity, information quality, and, in parts, ability show a tendency we assumed, but these differences are not significant.

Differences in evaluating trust dimensions between users and non-users

Regarding hypothesis 4 , we did not find any differences concerning evaluation of ability, benevolence, integrity, and information quality as dimensions of trust between people who use both traditional and special media sources and people who do not use media coverage at all for getting information about the company/CEO (see Tables VI and VII).

Therefore, hypotheses 4 must be rejected. But we did find differences between people who use media infrequently and respondents with frequent usage of traditional media. People who used traditional media, systematically evaluated trust overall and the dimensions in a more negative way than people who do not use any media coverage frequently for getting information about companies/CEOs. As shown in Table VI, the group with infrequent media use evaluates trust overall with an average of 2.76, whereas traditional media users have an average of 3.18. The same tendency is observable in the subdimensions of trust: Regarding ability, evaluation of 2.17 for elaborateness and 1.75 for product quality is significantly more positive for the non-users than for the users of traditional media (2.50 and 2.10). Also, the dimension benevolence with the items adequate public information (3.01 vs. 3.46) and social responsibility (3.04 vs. 3.62) differ in the same direction between the two groups. For integrity, the item activity is in accordance with promises (2.35 vs. $2.67)$, and for information quality, the item intelligible information/intelligibility (2.30 vs. 2.60$)$ shows a significant difference.

\section{Discussion and limitations}

Trust is significantly important for a company's ongoing success. This is not only true for the company as an organization, but also for the CEO's ability to establish trust in stakeholders. This strengthens the long-term relationship between stakeholders and the company. In order to analyze what influences trust building in companies, it is important not only to analyze the organization, but also the individual, the CEO as trustee. Our study 
Trust in Companies and in CEOs

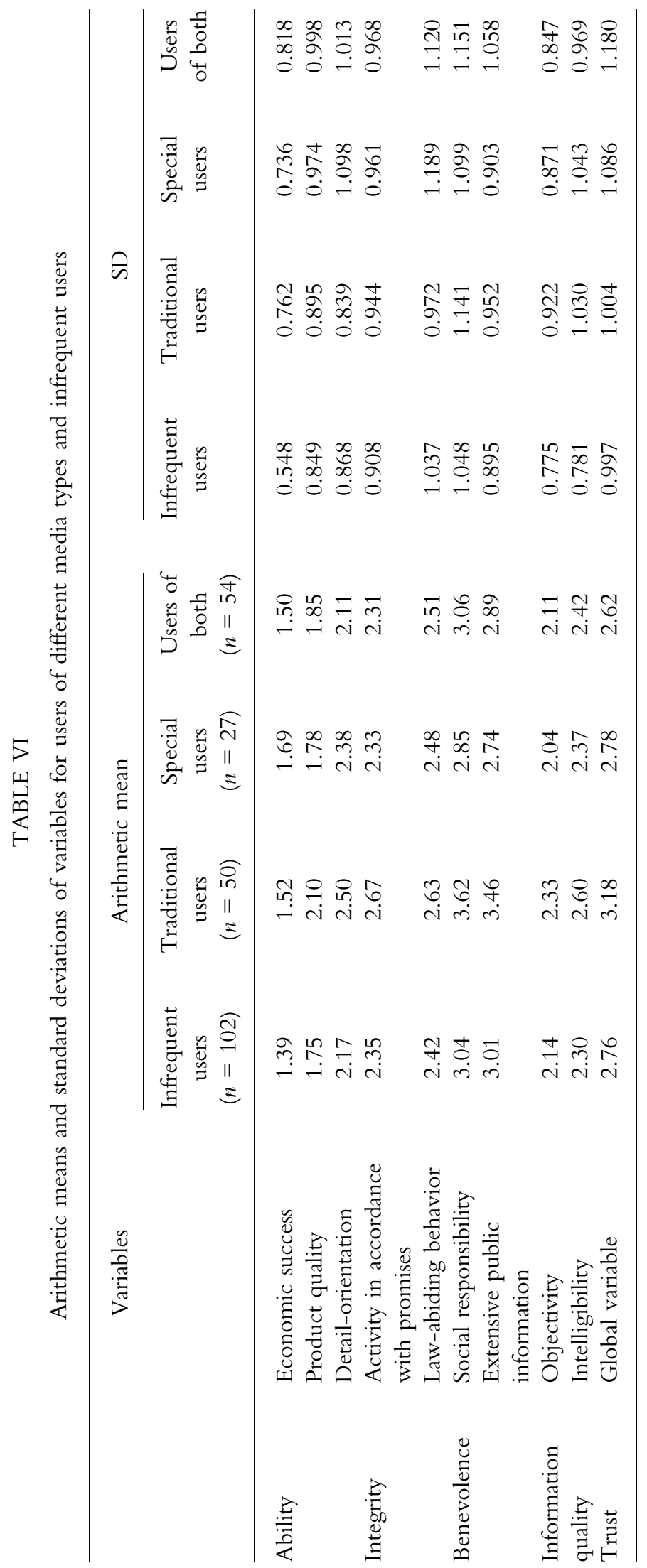




\section{TABLE VII}

$T$-values for arithmetic differences between the different user groups of media

\begin{tabular}{|c|c|c|c|c|}
\hline & Variables & $\begin{array}{l}T \text {-values for diff. } \\
\text { traditional versus specific }\end{array}$ & $\begin{array}{c}T \text {-values for diff. } \\
\text { both media versus } \\
\text { no media }\end{array}$ & $\begin{array}{l}T \text {-values for diff. } \\
\text { traditional } \\
\text { versus no media }\end{array}$ \\
\hline \multirow{3}{*}{ Ability } & Economic success & -0.946 & -0.871 & -1.183 \\
\hline & Product quality & 1.464 & -0.594 & $-2.310^{\star}$ \\
\hline & Detail-orientation & 0.511 & 0.343 & $-2.248^{\star}$ \\
\hline \multirow[t]{2}{*}{ Integrity } & Activity in accordance with promises & 1.494 & 0.244 & $-2.005^{\star}$ \\
\hline & Law-abiding behavior & 0.599 & -0.494 & -1.200 \\
\hline \multirow[t]{2}{*}{ Benevolence } & Social responsibility & $2.855^{\star \star}$ & -0.092 & $-3.109 \star$ \\
\hline & Extensive public information & $3.220 \star \star$ & 0.753 & $-2.852^{\star}$ \\
\hline Information & Objectivity & 1.312 & 0.187 & -1.232 \\
\hline quality & Intelligibility & 0.929 & -0.722 & -1.795 \\
\hline Trust & Global variable & 1.630 & 0.789 & $-2.408^{\star}$ \\
\hline
\end{tabular}

$\star$ Significant with $p \leq 0.05 ; \star \star$ Significant with $p \leq 0.01$.

contributes to clearing the differences between trust in companies and trust in CEOs. Therefore, we asked whether a difference exists between the degrees of trust in companies and in CEOs (hypothesis 1). Results show that CEOs were significantly evaluated more negatively regarding trust than companies as collective trustees. These findings indicate that respondents rate individuals much more critically than collectives regarding ability, benevolence, and integrity. One reason could be that a CEO is criticized in public, especially by the media, for losses and thus for decision-making mistakes in leading a company. Therefore, they are frequently replaced, whereas a company lasts and is merely regarded as an organization which depends on the decisions of a responsible CEO. Thus, trust in companies is built as an accumulation of decisions taken by the companies for a long period of time and, therefore, by different and changing CEOs.

Regarding the differences in the impact of ability, integrity, benevolence, and information quality on trust in CEOs and companies (hypothesis 2), it could be shown that the first three dimensions are important for overall trust on both individual (CEO) and collective (company) levels. Nevertheless, different aspects are important for building trust for CEOs and companies. For example, ability has an impact on overall trust in CEOs, because detail-orientation of the CEO is regarded as important. For companies, in contrast, detail-orientation does not have a significant influence but quality of products is crucial. This is not surprising as products are usually linked with companies as a whole and not with a CEO. Regarding integrity, it is important for the respondents that the CEO acts in accordance with his promises, whereas the company should abide by the law. Benevolence is especially important for trust in companies, because both items have a significantly positive impact. Social responsibility is influential both for CEOs and companies. But, for being positively influential on the company's success, stakeholders have to notice social activities of both the company and CEO. Thus, effective communication strategies are needed.

Regarding RQ1 it can be stated that trust in CEOs and in companies differs in the degree of overall trust, because CEOs are evaluated more critically than companies. Ability, benevolence, and integrity play an important role in explaining the degree of trust, whereas the influential items differ between groups. Information quality does not have an impact on trust in general.

Regarding RQ2, differences between user groups of special versus traditional media were found for benevolence (hypothesis 3). Companies report their activities on Websites, and special-interest magazines have more space to cover stories about benevolent behavior, whereas newspapers and news on TV and 
radio focus particularly on topics like economic success and product quality. Therefore, users of special media sources are expected to get more information about benevolent activities.

Surprisingly, there is no difference in the degree of trust between people who do not use media at all and the group of respondents that uses both traditional and special media sources and is, therefore, highly informed (hypothesis 4). In order to explain this finding, differences between users of traditional media and non-users regarding trust and trust dimensions were analyzed, and significant differences were found. Users of traditional media evaluated items of the three dimensions and overall trust significantly more critically than non-users. Hence, people who are infrequently informed by media coverage do not evaluate people as negatively as those who get general information from traditional media. Non-users do not differ significantly from the group that is highly informed (special and traditional media use). These findings indicate that people who are informed in a general and, therefore, more superficial way are much more critical than people who infrequently get their information from the media and, therefore, use other channels for evaluating companies and CEOs, or people who use media information to a great extent and thus have extensive and multifaceted information. For companies and CEOs, it is, therefore, especially important to get positive coverage in general media regarding the dimensions that are important for building trust. Regarding our findings, the images of a CEO, who is detail-oriented, and a company which stands for high product quality should be established and strengthened especially in the general media.

Finally, in our study, CEOs and the companies were mentioned in a free way by respondents. Altogether, respondents predominantly named CEOs and companies they regarded as economically successful and as specialists in their industrial sector (93 and 88\%, respectively at least, agreed to the items). The arithmetic mean of economic success was, therefore, higher than the other trust items (1.57 for CEOs and 1.37 for companies). Thus, the internationally active companies/CEOs mentioned are perceived as economically successful, but less benevolent. ${ }^{2}$ Therefore, we do not have a high degree of variance regarding the ability dimension.
For further analysis, companies and CEOs should vary regarding their perceived economic success. Differences between industries should be controlled as well.

Swiss companies are mentioned most often, when asked about international companies. It can be assumed that Swiss respondents are constantly informed by the national media about internationally active Swiss companies and recall them primarily because frequent media coverage increases the accessibility of information.

In future studies, it would be interesting to analyze whether our findings are also significant for international companies in other host countries or whether cultural effects can be found regarding trust-building dimensions. Also, research on the relationship of media coverage about companies and CEOs with trust building could be an interesting and an important focus for further analysis.

\section{Notes}

1 The company Nestlé Swiss was mentioned most often (34 times), followed by UBS (18 mentionings), and Novartis (13). As CEOs, Marcel Ospel of UBS (30), Daniel Vasella of Novartis (15), and Bill Gates (Microsoft, 14) were recalled most frequently. Therefore, only companies and CEOs were mentioned by the respondents that are perceived as economically successful (at least at the time of the survey).

2 In addition to economically successful companies, the two other ability items - comprehensive attention to detail and product quality - are on average evaluated positively, with an arithmetic mean of 2.22 (elaborateness, CEO) and 1.90 (product quality, CEO) and 2.24 and 1.80 resp. (company). In contrast, adequate public information and social responsibility activities were evaluated lower than the other items for both companies and CEOs (a.m. for social responsibility $=3.24$ for $\mathrm{CEO}$ and $=3.06$ for companies, adequate information $=3.23$ and $=2.88$ ). This means, that benevolent activities, in particular, are evaluated as only moderate for both company and CEO.

\section{Appendix}

See Tables VIII and IX. 


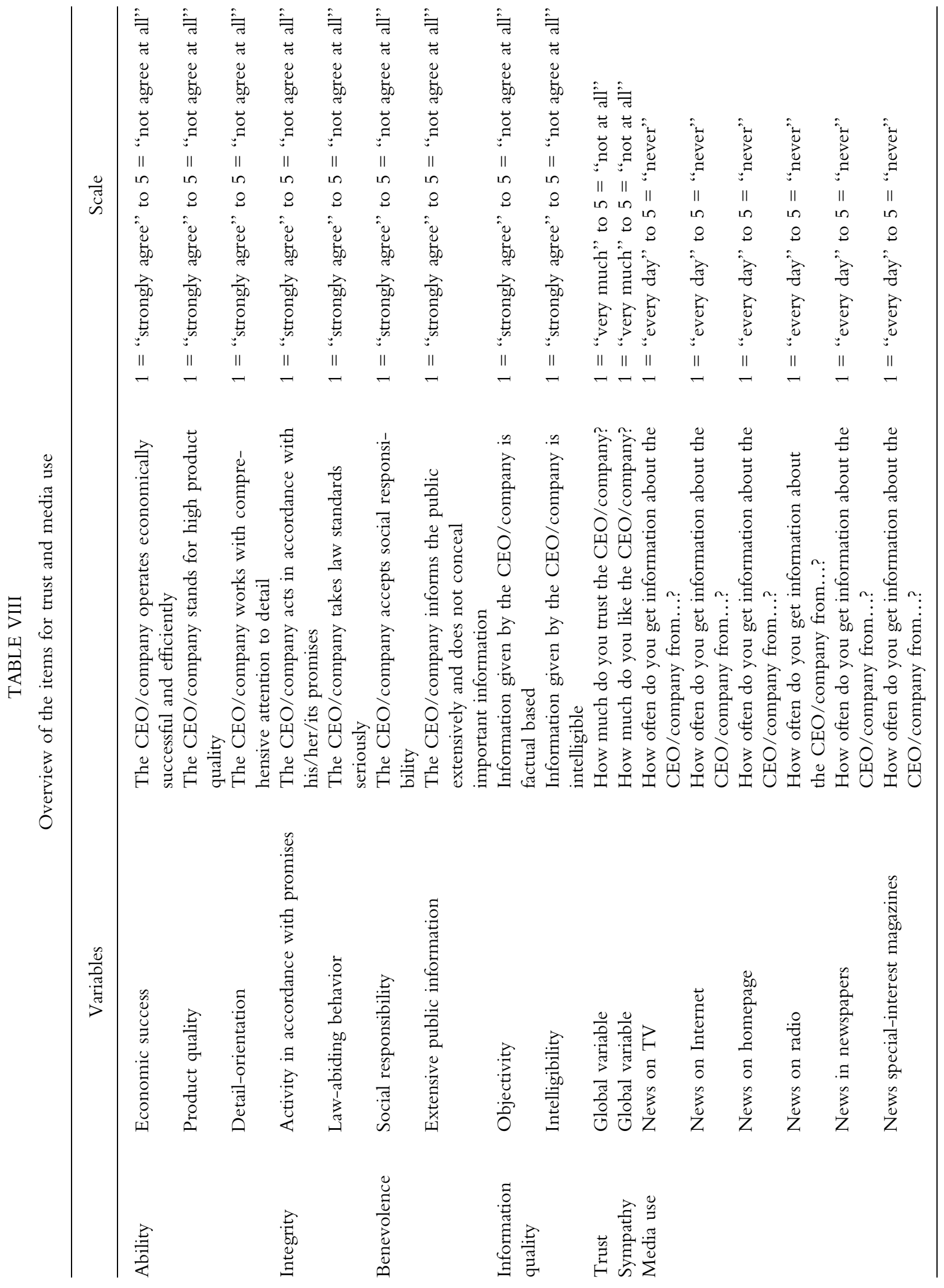




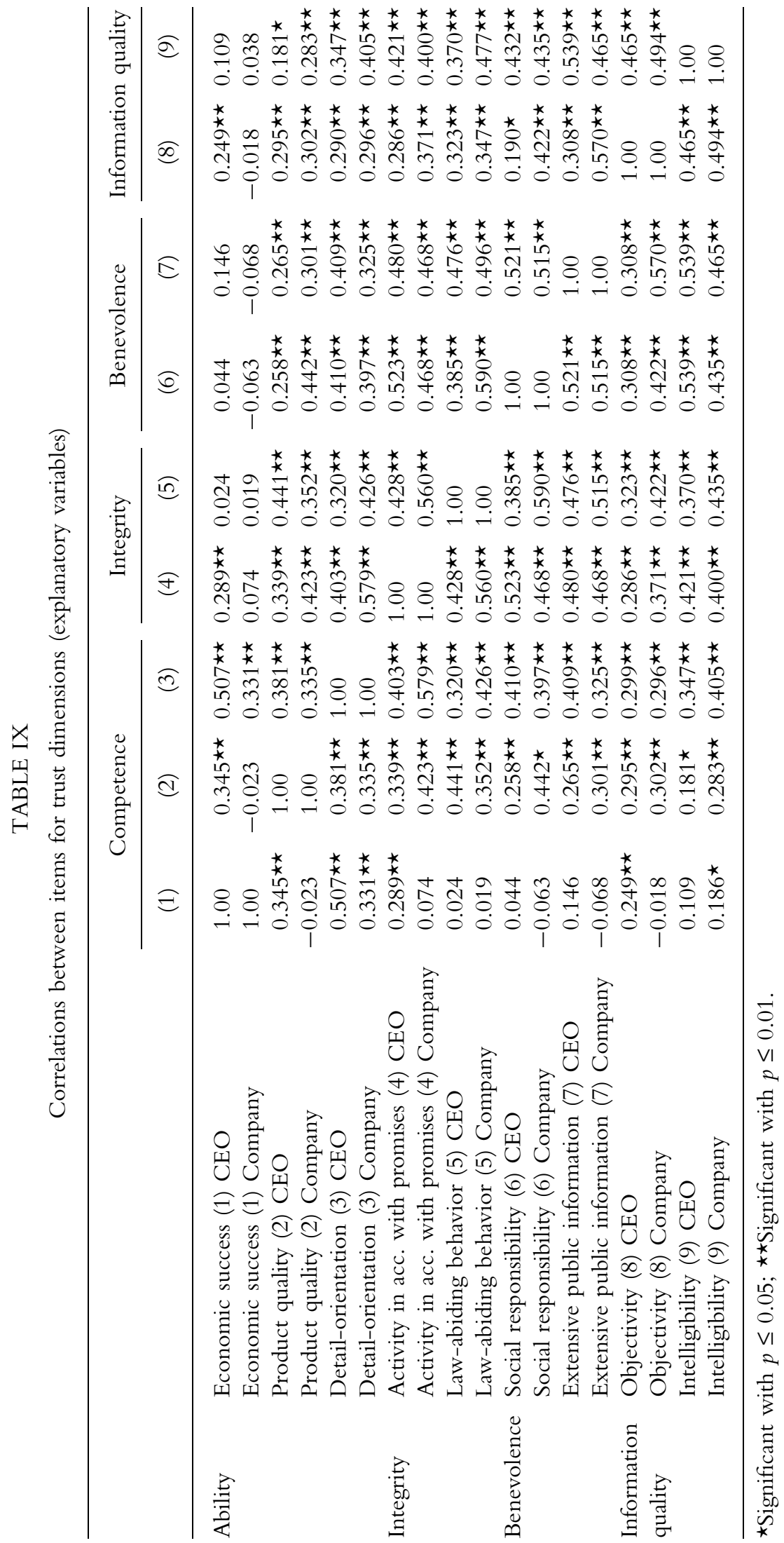




\section{References}

Barney, J. B. and M. H. Hansen: 1994, 'Trustworthiness as a Source of Competitive Advantage', Strategic Management Journal 15(4), 175-190.

Bentele, G.: 1994, 'Öffentliches Vertrauen - normative und soziale Grundlage für Public Relations', in W. Armbrecht and U. Zabel (eds.), Normative Aspekte der Public Relations (Eine Einführung, Opladen)), pp. 131-158.

Bentele, G. and R. Seidenglanz: 2005, 'Vertrauen und Glaubwürdigkeit', in G. Bentele, R. Fröhlich and P. Szyszka (eds.), Handbuch der Public Relations. Wissenschaftliche Grundlagen und berufliches Handeln (Verlag für Sozialwissenschaften, Wiesbaden), pp. 346-360.

Butler, J. K.: 1991, 'Towards Understanding and Measuring Conditions of Trust: Evolution of a Conditions of Trust Inventory', Journal of Management 17(3), 643663.

Butler, J. K. and R. S. Cantrell: 1984, 'A Behavioral Decision Theory Approach to Modeling Dyadic Trust in Superiors and Subordinates', Psychological Reports 55(1), 19-28.

Caldwell, C. and S. Clapham: 2003, 'Organizational Trustworthiness. An International Perspective', Journal of Business Ethics 47(4), 349-364.

Caldwell, C., B. Davis and J. A. Devine: 2008a, 'Trust, Faith, and Betrayal: Insights from Management for the Wise Believer', Journal of Business Ethics (Online).

Caldwell, C., L. A. Hayes, R. Karri and P. Bernal: 2008b, 'Ethical Stewardship - Implications for Leadership and Trust', Journal of Business Ethics 78(1-2), 153-164.

Carnevale, D. G.: 1995, Trustworthy Government: Leadership and Management Strategies for Building Trust and High Performance (Jossey-Bass Publishers, San Francisco, CA).

Christen, C. T.: 2004, 'Predicting Willingness to Negotiate: The Effects of Perceived Power and Trustworthiness in a Model of Strategic Public Relations', Journal of Public Relations Research 16(3), 243-267.

Cummings, L. L. and P. Bromiley: 1996, 'The Organizational Trust Inventory (OTI): Development and Validation', in R.M. Kramer and T. R. Tyler (eds.), Trust in Organizations (Sage, Thousand Oaks, CA), pp. 302-330.

Currall, S. C. and A. C. Inkpen: 2002, 'A Multilevel Approach to Trust in Joint Ventures', Journal of International Business Studies 33(3), 479-495.

Dimmick, J., Y. Chen and Z. Li: 2004, 'Competition Between the Internet and Traditional News Media: The Gratification-Opportunities Niche Dimension', Journal of Media Economics 17(1), 19-33.
Dyer, J. H. and W. Chu: 2003, 'The Role of Trustworthiness in Reducing Transaction Costs and Improving Performance: Empirical Evidence from United States, Japan, and Korea', Organization Science 14(1), 57-68.

Grunig, L. A., J. E. Grunig and D. M. Dozier: 2002, Excellent Public Relations and Effective Organizations. A Study of Communication Management in Three Countries (Lawrence Erlbaum, Mahwah, NJ).

Hardin, R.: 1991, 'Trusting Persons, Trusting Institutions', in R. Zeckhauser (ed.), Strategy and Choice (MIT Press, Cambridge, MA), pp. 185-209.

Hardin, R.: 2006, Trust (Polity Press, Cambridge).

Hon, L. C. and J. E. Grunig: 1999, Guidelines for Measuring Relationships in Public Relations (Institution for Public Relations, Gainesville, FL).

Hosmer, L. T.: 1995, 'Trust: The Connecting Link Between Organizational Theory and Philosophical Ethics', The Academy of Management Review 20(2), 379-403.

Huang, Y. H.: 2001, 'OPRA: A Cross-Cultural, Multiple-Item Scale for Measuring Organization-Public Relationships', Journal of Public Relations Research 13(1), 61-90.

Kaye, B. K. and T. J. Johnson: 2002, 'Online and the Know: Uses and Gratifications of the Web for Political Information', Journal of Broadcasting \& Electronic Media 46(1), 54-71.

Ki, E.-J. and L. C. Hon: 2007, 'Testing the Linkages Among the Organization-Public Relationship and Attitude and Behavioral Intentions', Journal of Public Relations Research 19(1), 1-23.

Kohring, M. and J. Matthes: 2007, 'Trust in News Media. Development and Validation of a Multidimensional Scale', Communication Research 34(2), 231-252.

Lämsä, A.-M. and R. Pucetaite: 2006, 'Development of Organizational Trust Among Employees from a Contextual Perspective', Business Ethics: A European Review 15(2), 130-141.

Luhmann, N.: 1979, Trust and Power (Wiley, New York).

Mayer, R., J. Davis and D. Schoormann: 1995, 'An Integrative Model of Organizational Trust', Academy of Management Review 20(3), 709-734.

McAllister, D.: 1995, 'Affect- and Cognition-Based Trust as Foundation for Interpersonal Cooperation in Organizations', The Academy of Management Journal 38(1), 24-59.

Möllering, G., R. Bachmann and S. H. Lee: 2004, 'Understanding Organizational Trust - Foundations, Constellations, and Issues of Operationalisation', Journal of Managerial Psychology 19(6), 556-570.

Möllering, G. and J. Sydow: 2005, 'Kollektiv, kooperativ, reflexiv: Vertrauen und Glaubwürdigkeit in 
Unternehmungen und Unternehmensnetzwerken', in B. Dernbach and M. Meyer (eds.), Vertrauen und Glaubwürdigkeit: Interdisziplinäre Perspektiven (Verlag für Sozialwissenschaften, Wiesbaden), pp. 64-93.

Nawratil, U.: 1999, 'Glaubwürdigkeit als Faktor im Prozess medialer Kommunikation', in P. Rössler and W. Wirth (eds.), Glaubwürdigkeit im Internet. Fragestellungen, Modelle, empirische Befunde (Fischer, München), pp. 15-32.

Park, D.-J. and B. K. Berger: 2004, 'The Presentation of CEOs in the Press, 1990-2000: Increasing Salience, Positive Valence, and a Focus on Competency and Personal Dimensions of Image', Journal of Public Relations Research 16(1), 93-125.

Rühl, M.: 2005, 'Vertrauen-kommunikationswissenschaftlich betrachtet', in B. Dernbach and M. Meyer (eds.), Vertrauen und Glaubwürdigkeit (Wiesbaden, VS Verlag).

Sako, M.: 1998, 'Does Trust Improve Business Performance?', in C. Lane and R. Bachmann (eds.), Trust Within and Between Organizations: Conceptual Issues and Empirical Applications (Oxford University Press, Oxford).
Shapiro, S. P.: 1990, 'Collaring the Crime, Not the Criminal: Reconsidering the Concept of White-Collar Crime', American Sociological Review 55(3), 246-365.

Skolnik, R.: 1994, 'Portraits of the "Most Admired Companies", Public Relations Journal 50(5), 14-18.

Urban, D. and J. Mayerl: 2006, Regressionsanalyse: Theorie, Technik und Anwendung, 2nd Edition (VS Verlag für Sozialwissenschaften, Wiesbaden).

Wirth, W.: 1999, 'Methodologische und konzeptionelle Aspekte der Glaubwürdigkeitsforschung', in P. Rössler and W. Wirth (eds.), Glaubwürdigkeit im Internet. Fragestellungen, Modelle, empirische Befunde (Fischer, München), pp. 47-66.

Zaheer, A., B. McEvily and V. Perrone: 1998, 'Does Trust Matter? Exploring the Effects of Interorganizational and Interpersonal Trust on Performance', Organization Science 9(2), 141-159.

University of Fribourg, Fribourg, Switzerland E-mail: diana.ingenhoff@unifr.ch 